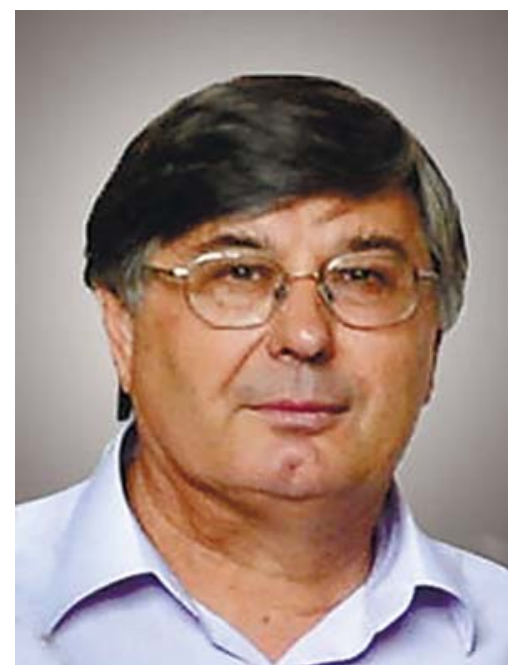

ТУКАЛО

Михайло Арсентійович академік НАН України, директор Інституту молекулярної біології і генетики НАН України

\section{ПРО УЧАСТЬ ВЧЕНИХ НАН УКРАЇНИ В ПРОТИДІЇ COVID-19. РОЗРОБЛЕННЯ ДІАГНОСТИЧНИХ СИСТЕМ, ЛІКАРСЬКИХ ЗАСОБІВ І МОНІТОРИНГ НЕБЕЗПЕЧНИХ ШТАМІВ}

\author{
За матеріалами доповіді на засіданні \\ Президії НАН України 9 червня 2021 року
}

Розглянуто основні напрями робіт науковців Інституту молекулярної біологї і генетики НАН України, спрямованих на протидію поширенню коронавірусної інфекиіі. Зокрема, створено першу вітчизняну тест-систему для ПЛР-діагностики SARS-CoV-2, яку згодом було суттєво вдосконалено. Розроблено комбіновану тест-систему для одночасної діагностики низки вірусів, а також маркерних генів. Тривають роботи зі створення лабораторї для пілотного виробництва генних конструктів для діагностичних тест-систем, вакцин, технологій створення лікарських засобів, імунобіологічних препаратів для лікування і профілактики COVID-19 та інших небезпечних захворювань. Інститут бере також активну участь у моніторингу нових штамів коронавірусу $S A R S$-CoV-2.

Вчені Інституту молекулярної біології і генетики (ІМБГ) НАН України в протидії поширенню коронавірусної хвороби COVID-19 працюють за такими основними напрямами:

1) створення та виробництво тест-систем для діагностики особливо небезпечних вірусних інфекцій, викликаних SARS$\mathrm{CoV}$-2 та іншими вірусами, зокрема розроблення комбінованих тест-систем;

2) моніторинг появи в Україні нових штамів вірусу SARS$\mathrm{CoV}-2$ шляхом секвенування;

3) комп'ютерне моделювання і пошук нових лікарських препаратів проти COVID-19;

4) створення вакцин на основі ДНК та РНК;

5) розроблення лікарських препаратів проти COVID-19 на основі РНК;

6) лікування хворих на пневмонію COVID-19 трансплантацією кріоконсервованих алогенних мезенхімальних стовбурових клітин (МСК). 
Чинники, які впливають на вибір напрямів досліджень, пов'язаних 3 протидією COVID-19, такі:

1) дані дослідження є важливим елементом національної безпеки країни. Це не остання пандемія, і ми маємо забезпечити Україну вітчизняними тестами, ліками, вакцинами;

2) швидка поява нових небезпечних штамів SARS-CoV-2;

3) низький рівень і темпи вакцинування населення України;

4) високий відсоток безсимптомних хворих;

5) постковідний синдром охопив сотні тисяч українців.

На всіх вказаних напрямах Інститут має наробки.

Розпочну з тест-систем для діагностики коронавірусу. Нагадаю, що на початку 2020 р. Інститут молекулярної біології і генетики НАН України визначено науковою установою, якій держава доручила розроблення і напрацювання діагностичних тест-систем на виявлення коронавірусу людини (рішення РНБО України від 13.03.2020 р., Указ Президента України № 87/2020 від 13.03.2020). Нами було

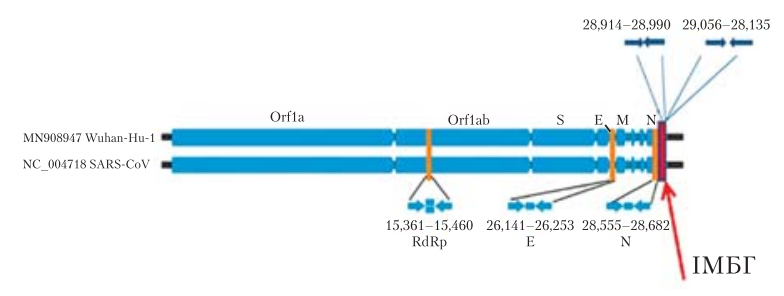

Puc. 1. Схема розташування праймерів для кПЛР порівняно з німецькою тест-системою (Corman V. et al.)

опрацьовано 18 послідовностей SARS-CoV-2, які були відомі на той час, і вибрано специфічні праймери для створення ПЛР тест-системи (рис. 1). Вона заклала основу для розроблення інших тест-систем, про які йтиметься далі.

Нагадаю, що коронавіруси є лише частиною агентів, які викликають гострі респіраторні захворювання. $€$ ще низка небезпечних вірусів, які потрібно вміти тестувати для чіткого встановлення діагнозу хвороби. 3 цією метою ми розпочали розроблення комбінованих ПЛР тест-систем для діагностики низки вірусів. Спочатку було створено і апробовано тестсистему для одночасної діагностики коронавірусу та вірусу грипу (рис. 2). Специфічність i
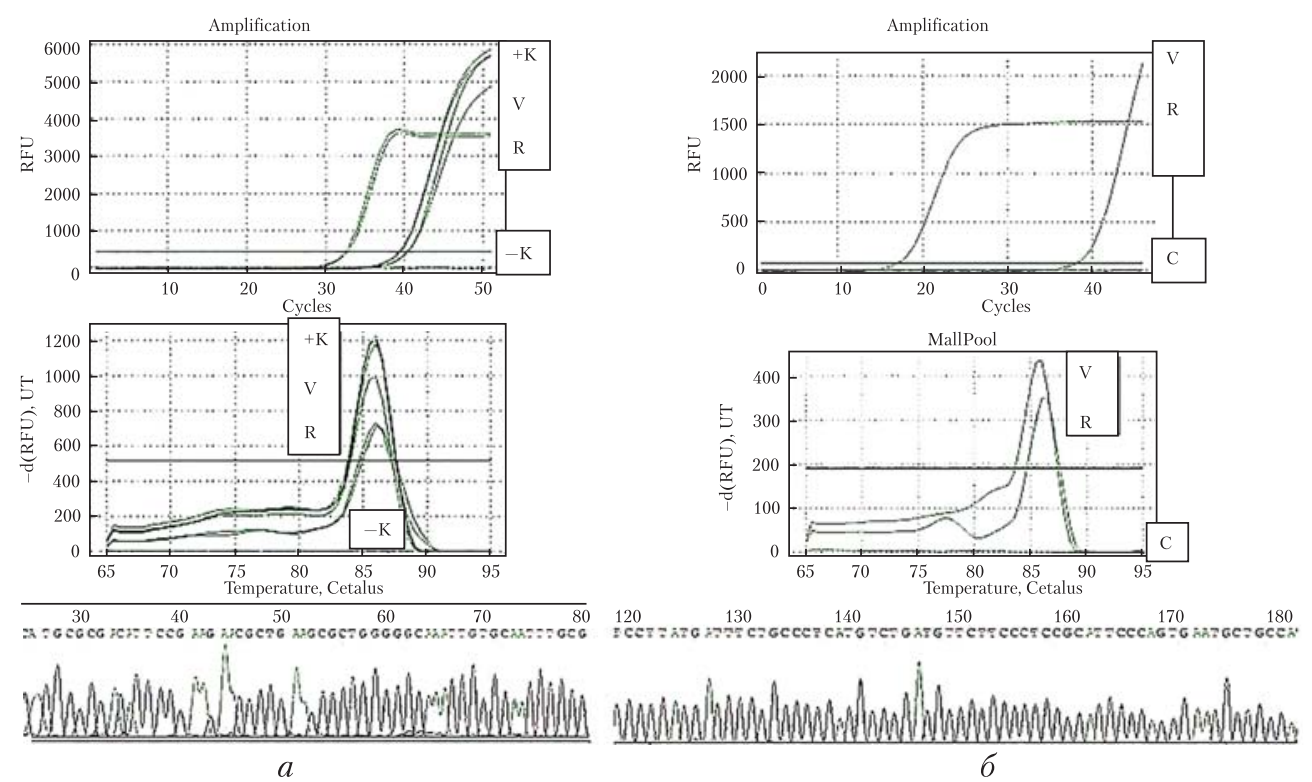

Puc. 2. Створення комбінованої ПЛР тест-системи на COVID-19 (a) та віруси A і В (б): +K - позитивний контроль; $-\mathrm{K}$ - негативний контроль; $\mathrm{V}$ - зразок пацієнта з праймерами на вірус; $\mathrm{R}$ - зразок пацієнта з праймерами на референсний ген; C - зразок пацієнта з праймерами на COVID-19 

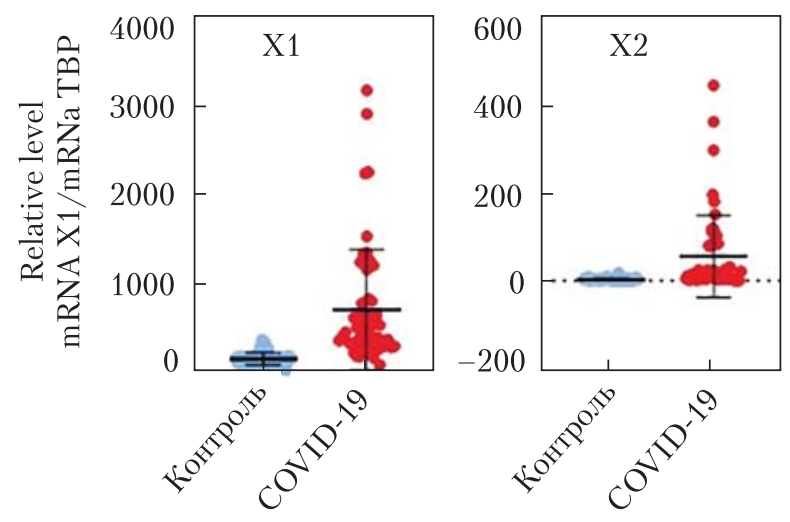

Puc. 3. Рівень мРНК генів у периферійних клітинах крові пацієнтів з COVID-19. **** ${ }^{*}<0,0001$ vs. Контроль. U-критерій Манна-Уітні. Контроль - здорові волонтери, $\mathrm{n}=59$; COVID-19 - пацієнти з хронічною формою COVID-19, $\mathrm{n}=52$
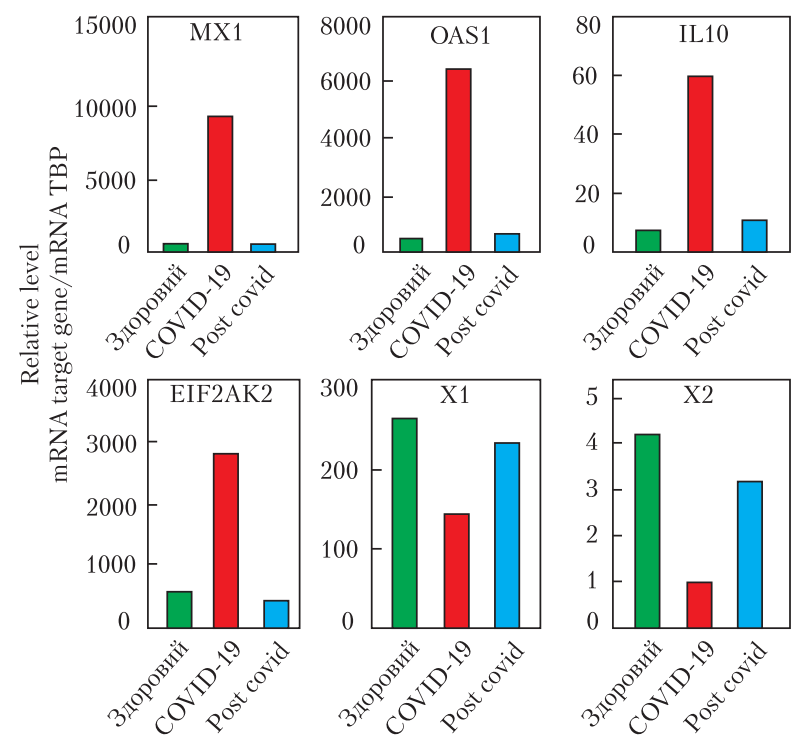

Puc. 4. Результати персоніфікованої діагностики гіперзапалення та порушення коагуляції крові у пацієнта $з$ COVID-19 та оцінка ефективності його лікування. Нормалізація рівня мРНК генів у периферійних клітинах крові пацієнта після лікування препаратом Нуклекс. Здоровий - пацієнт до пандемії COVID19; COVID-19 - пацієнт з позитивним тестом на SARSCoV-2; Post COVID19 - пацієнт після лікування COVID-19 з негативним тестом на SARS-CoV-2 надійність цієї тест-системи підтверджено секвенуванням отриманих продуктів ПЛР.

На сьогодні ми вже розробили комплексну тест-систему для одночасної діагностики 7 вірусів при ГРВІ з можливістю розширення як переліку вірусів, так і маркерних генів. Включення маркерних генів важливе при ранній діагностиці і лікуванні безсимптомних хворих та при лікуванні хворих з постковідним синдромом.

У цьому плані нами вивчено низку генів маркерів для ранньої діагностики гіперзапалення у пацієнтів з COVID-19. РНК для роботи виділялася 3 лейкоцитів крові пацієнтів. У результаті виявлено потенційні гени-маркери та створено тест-систему ранньої діагностики гіперзапалення у пацієнтів з COVID-19. Також нами вперше виявлено потенційні гени-маркери та створено тест-систему для діагностики порушення коагуляції у пацієнтів 3 COVID-19 (рис. 3). Нагадаю, що особливо важливо визначати експресію цих генів у пацієнтів з важкодіагностованими постковідними наслідками, яких зараз сотні тисяч.

Для невеликої кількості генів нам вдалося отримати інформацію відносно експресії генів у пацієнтів після лікування COVID-19. Встановлено, що рівень мРНК у периферійних клітинах крові після лікування приходить у норму. Ми також провели персоніфіковану діагностику гіперзапалення та порушення коагуляції крові у пацієнта з COVID-19, що дало можливість оцінити ефективність лікування. 3 рис. 4 видно, що в більшості випадків після лікування експресія маркерних генів повертається до норми.

В рамках цього проєкту ми вдосконалили раніше розроблену двокрокову ПЛР тестсистему. На прохання ЦГЗ МОЗ України ми створили однокрокову тест-систему без виділення РНК, що значно її здешевлює, оскільки не потрібно виділяти вірусну РНК і закуповувати високовартісні набори для їі виділення. А для використання в районних і селищних лікарнях ми створили спрощену і дешеву тестсистему, яка не потребує використання високовартісного приладу для контролю ПЛР-

ISSN 1027-3239. Visn. Nac. Acad. Nauk Ukr. 2021. (8) 
реакції в реальному часі, який коштує більш як 1 млн грн. Завдяки тому, що ми синтезували праймери, мічені, наприклад, біотином, ідентифікацію можна проводити шляхом простої хроматографії на стрічках.

Також ми проводимо інтенсивну роботу із заміни імпортних складових тест-систем, наприклад барвників-інтеркаляторів, на вітчизняні аналоги. Вони дешевші, кращі та ефективніші.

Другий напрям нашої роботи надзвичайно важливий для епідеміології та стратегічного прийняття рішень - моніторинг появи нових штамів SARS-CoV-2 в Україні шляхом секвенування. В Інституті відпрацьовано два основних підходи - швидкий (2 дні) та більш економний аналіз «гарячої» частини гена, який кодує, наприклад, S-білок, - швидка ідентифікація всіх наявних мутацій у досліджуваному регіоні для визначення циркулюючих уже відомих штамів SARS-CoV-2 та ефективності вакцин, і повногеномне секвенування вірусу 3 використанням методології секвенування наступного покоління. Так, шляхом секвенування 19 зразків геному коронавірусу SARSCoV-2, отриманих у лютому 2021 р. від ЦГЗ МОЗ України, на початку чергової хвилі захворюваності на COVID-19, встановлено, що всі ідентифіковані генотипи належать до класу 20I/501Y.V1, варіант VUI202012/01GRY (штам В.1.1.7 - «британський штам»). Також доведено, що цей штам потрапив в Україну значно раніше і як мінімум з трьох джерел. Ми вважаємо постійний моніторинг появи нових мутацій та штамів SARS-CoV-2 надзвичайно важливим для оцінки епідеміологічної ситуації в країні, особливо з появою в Свропі нового, більш трансмісивного «індійського штаму» (рис. 5).

Третій напрям стосується пошуку лікарських препаратів проти COVID-19 з використанням раціонального, мішень-спрямованого підходу, який включає комп'ютерне моделювання і докінг лігандів. У нашому Інституті у відділі білкової інженерії та біоінформатики ведеться така робота, де як мішень вибрано протеазу 3CLpro SARS-CoV-2. Проведено

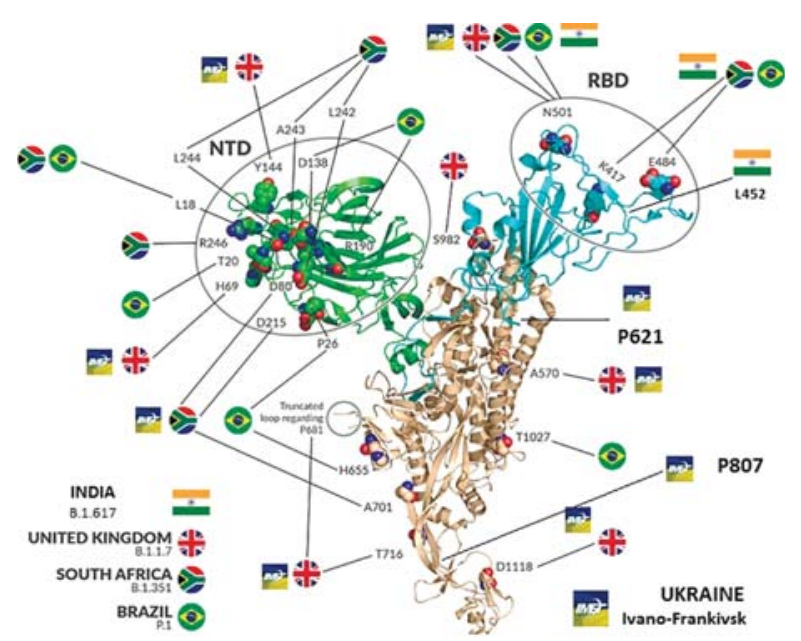

Puc. 5. Мутації в структурі S-білка коронавірусу SARS-CoV-2, виявлені у штамах британського, бразильського, південно-африканського, індійського та івано-франківського і київського варіантів. P621S і P807S - рідкісні мутації, виявлені в івано-франківському варіанті

комп'ютерне моделювання комплексу гліциризину (виділений з коріння солодки), який раніше показав ефективну противірусну дію, 3 протеазою SARS-CoV-2 з метою вивчення механізму його зв'язування в активному центрі протеази та можливого інгібування їі каталітичної активності. Наразі відпрацьовується генетична конструкція для експресії і виділення протеази, необхідної для біохімічного аналізу цього інгібітора, та інших, які будуть відібрані з бібліотеки із 250000 синтетичних компонентів.

Четвертий напрям має два піднапрями: a) створення вакцин на основі ДНК та РНК; б) лікарські препарати проти COVID-19 на основі РНК. Ми розробляємо унікальну ДНКвакцину на основі бакуловірусної системи. У бакуловірусну систему експресії буде вбудовано ДНК-фрагмент RBD S-білка, що включає мутаціі, які відповідають британському штаму SARS-CoV-2, з подальшим отриманням рекомбінантного бакуловірусу. Після трансдукції у клітини ссавців та введення піддослідним тваринам буде, відповідно, перевірено експресію цільового гена та наявність антитіл. 


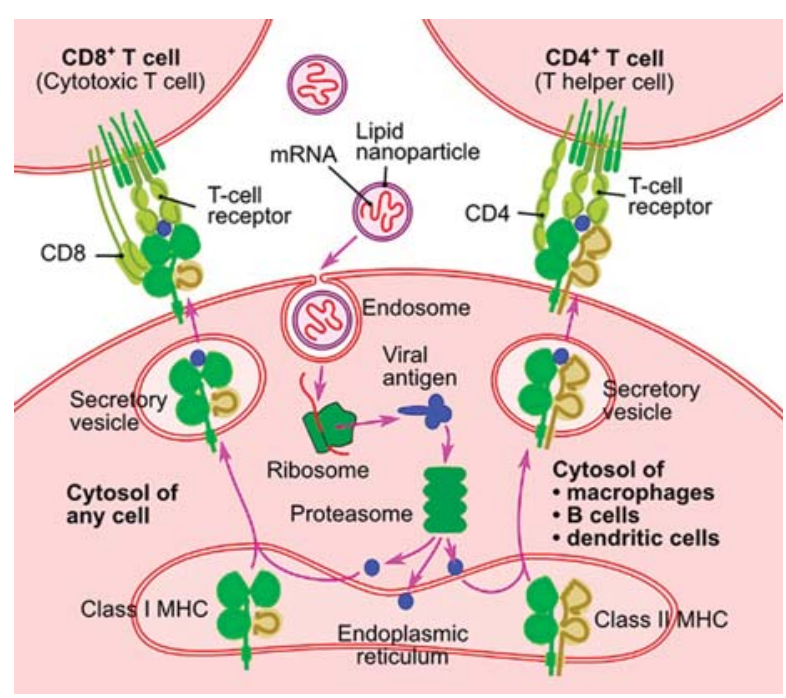

Puc. 6. Акцент на відпрацюванні методології ефективної доставки мРНК у клітини пацієнта

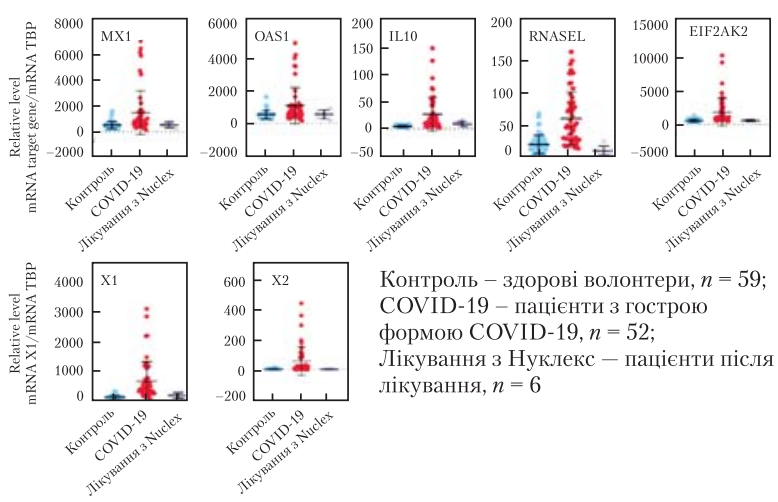

Puc. 7. Оцінка ефективності лікування препаратом Нуклекс пацієнтів з COVID-19

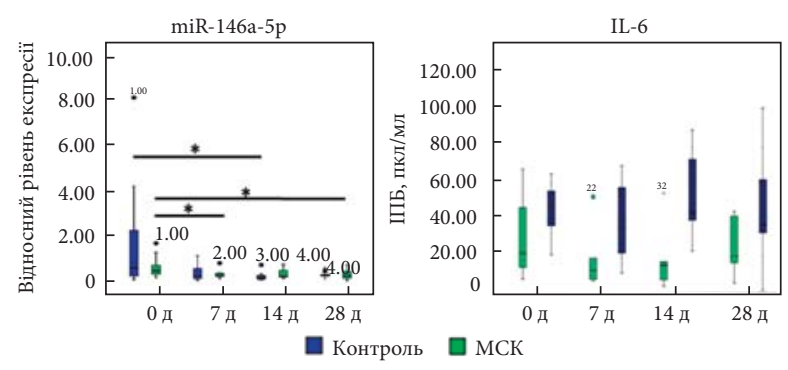

Puc. 8. Вплив трансплантації кріоконсервованих алогенних мезенхімальних стовбурових клітин на маркери запалення в крові хворих на COVID-19
Для отримання РНК-вакцини ми використовуватимемо цей самий фрагмент ДНК, який знаходиться під сильним промотором Т7 полімерази, для синтезу in vitro значних кількостей мРНК. Ми розуміємо, що в РНК-вакцинах усе дуже щільно запатентовано, і не маємо рожевих надій, що ці патенти будуть відкриті. Тому акцент робимо на відпрацюванні методології ефективної доставки мРНК у клітини пацієнта з використанням власних ноу-хау (рис. 6). Передбачається, що таку платформу буде використано для створення РНК-вакцин проти різних типів інфекційних та онкологічних захворювань.

Ми також вивчаємо лікарські препарати проти COVID-19 на основі РНК. Насамперед це Нуклекс, який створено на основі олігорибонуклеотидів дріжджової РНК з домінуючою фракцією 5-7 нуклеотидів у комплексі 3 D-манітолом. Раніше нами було показано противірусну (проти низки РНК-вірусів), протизапальну та антикоагуляційну активність Нуклексу. Оцінка лікування препаратом Нуклекс пацієнтів з COVID-19 показала його ефективність і засвідчила рівень мРНК-генів у периферійних клітинах крові пацієнтів 3 COVID-19, який свідчить про нормалізацію експресії генів і повне одужання (рис. 7).

В Інституті також ведуться дослідження стану дихальної, серцево-судинної та імунної систем у хворих на пневмонію, спричинену COVID-19, після трансплантації кріоконсервованих алогенних мезенхімальних стовбурових клітин. Наші експерименти стосувалися важких хворих, яким протягом 7 днів тричі вводили кріоконсервовані алогенні мезенхімальні стовбурові клітини (МСК). 313 важкохворих на COVID-19 пацієнтів, які отримали MCK, лише в одного залишився незначний фіброз легень. Встановлено, що трансплантація МСК приводить до зниження маркерів запалення в крові хворих на COVID-19, мікроРНК та інтерлікіну IL-6 (рис. 8).

Слід зазначити, що продемонстровані напрацювання мають важливе значення не лише для боротьби з пандемією COVID-19. Відпрацьовані платформи є основою для використання в майбутньому для боротьби з іншими

ISSN 1027-3239. Visn. Nac. Acad. Nauk Ukr. 2021. (8) 
поширеними захворюваннями. Тому найближчим часом потрібно вжити таких заходів:

1) посилити консолідацію зусиль вчених НАН України, НАМН України, МОН України та МОЗ України в боротьбі з небезпечними інфекціями; необхідно створити Центр біомедичних технологій (аналітичний центр, біокластери тощо);

2) поновити Державну цільову науково-технічну програму розроблення новітніх технологій створення вітчизняних лікарських засобів для забезпечення охорони здоров’я людини та задоволення потреб ветеринарної медицини або започаткувати нову Державну цільову науково-технічну програму створення та проведення доклінічних випробувань вітчизняних вакцин та лікарських засобів для забезпечення охорони здоров’я людини;

3) керівництву НАН України вкрай бажано звернутися до МОЗ України з клопотанням про забезпечення держзамовлення на виробництво вітчизняних тест-систем;

4) звернути увагу на підготовку кадрів та навчання медперсоналу;

5) посилити співпрацю з міжнародними організаціями у царині біобезпеки.

\section{Michael A. Tukalo}

ORCID: https://orcid.org/0000-0002-0982-2372

Institute of Molecular Biology and Genetics of the National Academy of Sciences of Ukraine, Kyiv, Ukraine

ON THE PARTICIPATION OF SCIENTISTS OF THE NAS OF UKRAINE IN COUNTERACTING COVID-19. DEVELOPMENT OF DIAGNOSTIC SYSTEMS, DRUGS AND MONITORING OF DANGEROUS STRAINS

According to the materials of report at the meeting of the Presidium of NAS of Ukraine, June 9, 2021

The main directions of work of scientists of the Institute of Molecular Biology and Genetics of the NAS of Ukraine aimed at counteracting the spread of coronavirus infection are considered. In particular, the first domestic test system for PCR diagnostics of SARS-CoV-2 has been created, which was later significantly improved. A combined test system has been developed for the simultaneous diagnosis of a number of viruses as well as marker genes. Work is underway to establish a laboratory for the pilot production of gene constructs for diagnostic test systems, vaccines, drug development technologies, immunobiological drugs for the treatment and prevention of COVID-19 and other dangerous diseases. The institute is also actively involved in monitoring new strains of coronavirus SARS-CoV-2.

Keywords: SARS-CoV-2, PCR diagnostics, test systems, strain monitoring, drugs against COVID-19. 